\title{
Biota toxicity to herbicide Paraquat in Brazilian Northeast littoral reservoirs: need for a biomonitoring program for watershed management
}

\section{José Etham de Lucena Barbosa ${ }^{1}$, Takako Watanabe' ${ }^{2}$, Robert Anthony Coler $^{2}$ and Ronilson José da $\mathrm{Paz}^{3}$}

${ }^{1}$ Universidade Estadual da Paraíba (UEPB), Centro de Ciências Biológicas e da Saúde, Departamento de Biologia, Rua Baraúnas, 351, Campus Universitário, CEP 58429-500, Campina Grande, PB, Brazil. E-mail: ethambarbosa@hotmail.com.

${ }^{2}$ Universidade Federal da Paraíba (UFPB), Centro de Ciências Exatas e da Natureza, Departamento de Sistemática e Ecologia, CEP 58051-900, João Pessoa, PB, Brazil.

${ }^{3}$ Instituto Brasileiro do Meio Ambiente e dos Recursos Naturais Renováveis (IBAMA), Caixa Postal 5063, CEP 58051-900, João Pessoa, PB, Brazil. E-mail: ronilson.paz@gmail.com.

\begin{abstract}
We present the original results of set of toxicity tests of the herbicide Paraquat, used in sugar cane fields, and the cultivation of pineapple and Eucalyptus, on zooplankton and benthos organisms from reservoirs of the Brazilian Northeast Littoral Zone. We demonstrate that Macrobrachium amazonicum (prawn), Pomacea lineata (snail) and Daphnia similis (cladoceran) are several orders of magnitude more sensitive than test organisms (aquatic insects, amphipods, and cladocerans) classically used in temperate regions. Combining typical herbicide application data together with rainfall and water level seasonality of Gramame Reservoir, we emphasize highly fluctuation patterns of toxicity for the other reservoirs in the region. Therefore, they urge the enforcement of management policies based on the implementation of a watershed-scaled biomonitoring program using the here employed test organisms. Reservoirs of the Brazilian Northeast was deteriorating (eutrophication, pollution; including frequent cyanobacteria blooming, often toxic), and multi-use management, particularly to meet the water drinking demand of rural and urban populations, is now a crucial need. The suggestion of implementing a biomonitoring program based on toxicity tests of particularly sensitive organisms are then more appropriate than a costly largescale high technology program. The use of locally dominant organisms instead of temperate standards is essential. The demonstrated high sensitivity of Daphnia species to Paraquat may well explain why rotifers often dominate the zooplankton in reservoirs of this region, as herbicides and pesticides are widely as well as intensively used in the Northeast Semi-Arid Regions (e.g. Agreste and Sertão).
\end{abstract}

Keywords: Biomonitoring, herbicide pollution, toxicity.
Received

April 11, 2014

Accepted

May 27, 2014

Released

June 30, 2014

Open Acess Full Text Article 


\section{Introduction}

The water resources of Northeast Brazil must be carefully managed if demands in the near future are to be met. While an active program to augment supply has been mounted by the National of Drought Management (Dnocs), comparatively little has been done with regard to water quality (Watanabe et al., 1999). Presently it seems satisfying priorities for irrigation has preempted those for public consumption, aquaculture and ecology. Good water management, in the form of programs to control the application of fertilizers and agrotoxins, provides a means for diminishing deterioration of potable water quality and increasing protein production. No such multiple-use management programs have been implemented, yet erosion and loss of fertilizers and agrotoxins to the water body have resulted in pollution (Ceballos et al., 1995), blue green-algae blooms (Watanabe et al., 1994), and deterioration of the fishery.

Probably the most critical problem that need be addressed is herbicide pollution, because the lakes of the Brazilian Littoral Zone are ultraoligotrophic so some organic enrichment due to sugar cane pollution and fertilizers could well enhance the fishery.

The intense rainfalls, sandy nonretentive soils (Luchini et al., 1981) and steep shoreline predispose to a particularly mobile and ubiquitous herbicide molecule. To achieve a measure of success in such a marginal environment, we could improve water quality through upgrading farming practices. The farmer must be made aware that farming to maximize harvest is not sustainable farming and that he can reduce application levels of agrotoxins and fertilizers, improve family health and maintain the diversity of the biota, without loss of income. The difficulty is that inauguration of remedial measures must include some method to assess their efficacy. There is an urgent need to monitor water quality, but the prohibitive cost of gas chromatography and atomic absorption precludes the mounting of any large scale instrumentation based monitoring program.
Further, mere presence of a chemical is not to be equated with its bioavailability. Biomonitoring, on the other hand, integrates and predicts the synergistic and antagonistic impact of the total environment on survival and growth. Biomonitoring supplemented with artificial substrates and live traps, would provide the yard stick to asses the efficacy of remedial measures, conformity to application remedial measures, conformity to application regulations and identify impeding crises.

Preliminary data generated in our laboratory indicate that crustaceans and molluscs (dominant constituents of the benthos of the Northeast) are particularly vulnerable to herbicides. In this context, because of their critical role in the food web and value as early warning indicators, it would be important to include them as principal indicator species. We undertook, therefore, short-term abbreviated, rangefinding LC50 and chronic level EC50 determinations to learn if the disparities between reported and observed toxicities to Paraquat, a dipyrimidene herbicide, commonly used in the culture of sugarcane, do in fact exist (Gonçalves et al., 1992; Schmitt et al., 2006; Medeiros and Cruz, 2009).

Using limnological and toxicological data from Gramame Reservoir, a biomonitoring and management program for the Brazilian Northeast Littoral Zone reservoirs is proposed at the watershed scale.

\section{Methods}

The methodology employed to assay acute and chronic toxicity of Paraquat generally conformed to the appropriate sections listed in Eaton et al. (1995). In those instances where they were modified they followed the procedures outline by Buikema et al. (1980) for Daphnia similis, Batalla (1997), Melo et al. (2000) and Coler et al. (2005) for the snail Pomacea lineata, and Aragão et al. (1998) and Coler et al. (1999) for the prawn Macrobrachium amazonicum. 
Table 1. Acute and chronic toxicities of Paraquat to indicated organisms.

\begin{tabular}{|c|c|c|}
\hline \multirow{2}{*}{ Organism } & \multicolumn{2}{|c|}{ Toxicity } \\
\hline & Acute & Chronic (EC50) - 21 days \\
\hline Dapnia similis $<24 \mathrm{~h}$ neonates & $48 \mathrm{~h} \mathrm{LC50} 0.017 \mu \mathrm{g} \mathrm{L}^{-1}$ & $\begin{array}{l}\text { Progeny }=0.0015 \mu \mathrm{g} \mathrm{L}^{-1} \\
\text { Progeny } / \text { ind. }=0.005 \mu \mathrm{g} \mathrm{L}^{-1}\end{array}$ \\
\hline Macrobrachium amazonicum juveniles & 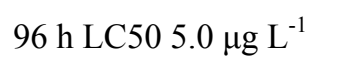 & Respiration $=0.035 \mu \mathrm{g} \mathrm{L}^{-1}$ \\
\hline Pomacea lineata 3-4 days neonates & $\begin{array}{l}\text { LOMC } 0.15 \mathrm{mg} \mathrm{L}^{-1} \\
\text { NOMC } 0.07 \mathrm{mg} \mathrm{L}^{-1}\end{array}$ & \\
\hline
\end{tabular}

According to USEPA (1997), Paraquat Dichloride is an herbicide currently registered to control weeds and grasses in many agricultural and nonagricultural areas. It is used preplant or preemergence on vegetables, grains, cotton, grasses, sugar cane, peanuts, potatoes, and tree plantation areas; postemergence around fruit crops, vegetables, trees, vines, grains, soybeans, and sugar-cane; during the dormant season on clover and other legumes; as a desiccant or harvest aid on cotton, dry beans, soybeans, potatoes, sunflowers, and sugar cane; and as a post harvest desiccant on staked tomatoes.

In Northeast Brazil, Paraquat is an herbicide widely used in agriculture, in sugar-cane fields, and the cultivation of pineapple and Eucalyptus (Gadelha et al., 2001).

\section{Results and discussion}

Our laboratory data indicate that Paraquat may not be as benign to aquatic invertebrates as believed (Medeiros et al., 2001). Its wide acceptance throughout the world stems from its reportedly acute toxicity to weeds, rapid degradation and almost negligible impact on animals (Hellawell, 1986). Brooker and Edwards (1974) noted that in a field test, the diminution of aquatic macroinvertebrate populations could be attributed to the loss of habitat or food source but not to toxicity directly. It may be, however, that the toxicity data generated with temperate test species do not permit extrapolation to those of the tropics. Further, the spectrum of orders chosen to represent the aquatic community, in the UK and USA does not represent the biota of Northeast Brazil. Herbicide clearance was, aside from daphnids fish, and algae, based largely on the response of insect nymphs. Here, the benthic macroinvertebrate community is comprised principally of freshwater prawn and snails with occasional odonates and chironomids (Abílio, 1997).

No testing methods have as yet been adopted by Standard Methods (Eaton et al., 1995) for the orders of either one of these dominants. This may be a serious omission because the LC50's for aquatic insects were generally greater than for crustaceans. The respective $96 \mathrm{~h}$ LC50's for Pteronarcys californica, Limnephilus sp, and Callibaetis sp were $>100,33$ and $16.4 \mathrm{mg} . \mathrm{L}^{-1}$. The crustaceans Hyalella an amphipod and Asellus an isopod, on the other hand, had LC50's of $50 \mathrm{mg} . \mathrm{L}^{-1}$ and less than $1 \mathrm{mg} . \mathrm{L}^{-1}$ respectively (MuirheadThompson, 1987). With regard to our data, interpolation on a log-probit scale yielded much lower LC50's and EC50's (Table 1).

Acute toxicity values for Paraquat with Daphnia similis are three orders of magnitude less than the $4 \mathrm{mg} . \mathrm{L}^{-1}$ LC50 reported for Daphnia pulex by Sanders and Cope (1961). The acute toxicity data generated by Batalla (1997) with Pomacea lineata though orders of magnitude greater are still acutely toxic at microgram levels. Macrobrachium, as well as, at $5 \mathrm{mg} . \mathrm{L}^{-1}$ proved significantly more sensitive to Paraquat than one would expect from organisms of temperate latitudes. It may be that Mullison's blanket acceptance of herbicides (Hellawell, 1989) does not extend to snails and crustaceans. 
Table 2. Total quantitity of water consumed monthly by irrigation (x $\left.103 \mathrm{~m}^{3}\right)$ of the principal crops harvested in Gramame Reservoir.

\begin{tabular}{lrrrcrrrrr}
\hline Culture & $\begin{array}{c}\text { Area } \\
\text { (ha) }\end{array}$ & \multicolumn{1}{c}{ Jan } & Feb & $\begin{array}{c}\text { Mar to } \\
\text { Aug }\end{array}$ & Sept & Oct & Nov & Dec & Total \\
\hline Pineapple & 179 & 342 & 300 & 0 & 277 & 323 & 331 & 342 & 1,917 \\
Banana & 23 & 64 & 56 & 0 & 33 & 49 & 50 & 64 & 319 \\
Sugr-cane & 8,974 & 20,400 & 18,007 & 0 & 16,601 & 19,473 & 19,742 & 20,400 & 114,627 \\
Elephant grass & 24 & 60 & 53 & 0 & 49 & 58 & 58 & 60 & 341 \\
Coconuts & 147 & 296 & 260 & 0 & 242 & 288 & 286 & 296 & 1,670 \\
Bean plant & 46 & - & - & 0 & 66 & 123 & 112 & - & 302 \\
Yam & 125 & 218 & 215 & 0 & 112 & 133 & 135 & 202 & 1,018 \\
\hline Total & 9,546 & 21,418 & 18,927 & 0 & 17,423 & 20,509 & 20,780 & 21,423 & 120,285 \\
\hline
\end{tabular}

Modified from Campos et al. (2002).

Table 3. Trophic status (based on an average of 10 readings) of Gramame Reservoir durant dry and rainy seasons of 1991 thru 1993, using Carlson's index (1977) modified by Toledo et al. (1983) as indicated by ortophosphate $\left(\mu \mathrm{g} . \mathrm{L}^{-1} \mathrm{PO}_{4}-\mathrm{P}\right)$, Chlorophyll $\alpha\left(\mu \mathrm{g} \cdot \mathrm{L}^{-1}\right)$, and Secchi depth (cm).

\begin{tabular}{cccccc}
\hline \multirow{2}{*}{ Season } & \multicolumn{4}{c}{ Trophic status index (TSI) } \\
\cline { 3 - 6 } & & PO $_{\mathbf{4}}-\mathbf{P}$ & Chlorophyll $\boldsymbol{\alpha}$ & Secchi disc & Weighted Average \\
\hline \multirow{2}{*}{1991} & Dry & 50.9 & 53.9 & 48.2 & 48.3 \\
& Rain & 36.8 & 45.6 & 42.9 & 41.1 \\
\hline \multirow{2}{*}{1992} & Dry & - & 49.1 & 47.0 & 48.1 \\
& Rain & - & 49.2 & 42.3 & 45.6 \\
\hline \multirow{2}{*}{1993} & Dry & 59.1 & 47.8 & 44.0 & 48.3 \\
& Rain & 46.5 & 42.8 & 44.0 & 43.3 \\
\hline
\end{tabular}

TSI $<44=$ Oligotrophic; TSI $>44$ and $<54=$ Mesotrophic; TSI $>54=$ Eutrophic

If we assume twice weekly the standard application levels of $5 \mathrm{~L}$ gramoxone. $\mathrm{h}^{-1}$ or $100 \mathrm{mg} \cdot \mathrm{m}^{-2}$ Paraquat (ICI, 1990), it is possible visualize a scenario where run-off and erosion could achieve concentrations in the bordering littoral zone in excess of the LC50's reported (Table 1). When considering chronic toxicity, the potential for stress become yet more probable. If these populations concentrate in the littoral zone and the entire perimeter of the water body is under cultivation, the run-off before dilution in the deeper waters could reduce productivity of primary and secondary consumers. Watanabe et al. (1994) in fact reported concentrations of herbicides in her samples while studying primary productivity in Gramame Reservoir and Medeiros and Cruz (2009) identified the herbicide Paraquat responsible for pesticide intoxication in State of Paraíba. In light of the values reported here, it would seem that toxicity testing must emphasize the routine use of crustaceans and Braz. J. Biol. Sci., 2014, v. 1, n. 1, p. 21-27. molluscans to monitor water quality. This practice would provide quality assurance if not quality control (Table 2).

Our great reservoirs in the Littoral Zone then are not lakes, but merely impoundments. The aquatic biota eke out an extremely tenuous environment. Secondary productivity is low because scouring and flushing prevent formation of a stable littoral zone with phosphorous rich sediments that would support a detritus based food web. Succession is stymied by unstable water levels due to: evaporation, flooding, irrigation and use a potable water source. This combined with pollution from agrotoxins, fertilizers and run-off conspire to produce a hostile, and at times violent habitat.

The relevance of these observations became immediately apparent when one considers the distribution in time and intensity of rainfall in Northeast Brazil. After 6-7 months of scant rainfall the Littoral Zone reservoirs are reduced to 
about $1 / 3$ of their storage capacity due to evapotranspiration and municipal demands. For example, the Gramame Reservoir has an average (1998-1999) flushing rate of $2.1 \mathrm{~m}^{3} \cdot \mathrm{s}^{-1}$ (a conservative estimate reflecting the impact of El Niño imposed drought conditions in 1999). The flushing process is confined essentially to four months when $75 \%$ of the annual rainfall $(1,880 \mathrm{~mm})$ occurs (National Weather Bureau). Cultivation follows the receding water level until April or May (depending on the region), when the rains begin and the agrotoxins/fertilizers applied most recently to the crops at the closest proximity to the surface of the reservoir, become incorporated by the rising waters, erosion, percolation and run-off (MuirheadThompson, 1987). During this period the frequency of herbicide applications is increase to compensate for that fraction carried off by the rain. Under such prevailing conditions the sock effect of this first flush could be significant both with regard to the public health and ecology. With the ensuing chronic toxicity, overharvesting and the loss of forage there occurs a progressive diminution of the fishery as well. We can anticipate a saw tooth-like sequence where toxicity is most marked in the early rainy season when the mesotrophic run-off has not yet attenuated the stress imposed by the herbicide on the aquatic biota. With continued rainfall, the buffered, nutrient laden run-off stimulates productivity which plateaus, and then drops gradually with the onset of the dry season.

This scenario is supported by the data (Table 3) generated by Barbosa (1996). Applying the trophic status indicators evolved by Carlson (1977) and modified by Toledo et al. (1983) for tropical water bodies, he determined that trophic status oscillated oligotrophic during the dry season and meso/eutrophic during the rainy season. During this same interval (1991-1993), the dominant phytoplankton in the dry and wet periods, respectively were: the oligotrophic indicators: Oocystis asymetrica and Botryococcus braunii, and the eutrophic indicators: Microcystis aeruginosa and Volvox aureus. Similarly the dominant zooplankton trophic state indicators in the dry and wet period were: the oligotrophic Notodiaptomus cearensis and the eutrophic cyclopoids Thermocyclops sp. and Paracyclops sp. Further, species diversity was greater among both groups during the dry period.

With these constraints, then, we are faced with defining a lake management policy that is consistent with the perspective of the watershed as a renewable resource; a resource that can absorb and process a limited intensity of environmental insult for some months without excessive diminution of its agricultural, aquacultural and cattle cultural capacities. These poorly buffered, ultraoligotrophic impoundments (Barbosa, 1996) incapable of sustaining a vigorous aquatic community, should be treated as holding ponds rather than ecological entities. In a region beset by protein deficiency, it is incumbent upon the government to exploit all sources of protein. Enough is known about fish and habitat management to produce a marginally sustainable fishery.

In this regard, a rather significant effort in fish stocking has been made by Dnocs (Gesteira, 1978). Their efforts have not met with notable success however because little attempt was made to manage impoundments. Such restoration strategies as stocking (i.e. all male tilapia), manipulation of $\mathrm{pH}, \mathrm{CO}_{2}$, and aeration to control blue-green algae, planting nitrogen fixers and soil stabilizers, cage culture, and modifying habitat through installation of cover, gabions and breeding substrates are all valid management tactics.

\section{References}

Abílio, F. J. P. Aspectos bio-ecológicos da fauna malacológica, com ênfase a Melanoides tuberculata Muller, 1774 (Gastropoda, Thiaridae) em corpos aquáticos do Estado da Paraíba. João Pessoa: Universidade Federal da Paraiba, 1997. (Masters Thesis).

Aragão, R. M.; Xavier, B.; Coler, R.; Watanabe, T. A preliminary study of respiration and excretion rates in prawn Macrobrachium amazonicum when exposed to varied flow regimes and salinities. Rev. Nordestina Biol., v. 12, p. 1-8, 1998.

Barbosa, J. E. L. Comportamento nictemeral do fitoplâncton e dos parâmetros hidrológicos na Represa de Gramame, Alhandra - Paraíba. Recife: Universidade Federal de Pernambuco, 1996. (Masters Thesis).

Braz. J. Biol. Sci., 2014, v. 1, n. 1, p. 21-27. 
Batalla, J. F. Efeito do herbicida Paraquat sobre o gastrópode Pomacea lineata (Spix, 1827) (Ampullariidae, Prosobranchia): Bioensaios em laboratório. João Pessoa: Universidade Federal da Paraíba, 1997. (Masters Thesis).

Brooker, M.; Edwards, R. Effects of the herbicide Paraquat on the ecology of a reservoir. III. Fauna and general discussion. Freshwater Biology, v. 4, p. 311-335, 1974.

Buikema, A. L.; Geiger, J. G.; Lee, D. R. Daphnia toxicity tests. Aquatic Invertebrate Bioassays, v. 3, p. 48-69, 1980.

Campos, L. F.; Quirino, U. C. M.; Gadelha, C. L. M. Abastecimento industrial: estimativa da demanda na Bacia do Rio Gramame no Estado da Paraíba. In: Gadelha, C. L. M.; Silva, T. C.; Passerat de Silans, A. M. B. (Org.). Bacia do Rio Gramame: hidrologia e aspectos ambientais para gestão dos seus recursos hídricos. João Pessoa: Editora Universitária/ UFPB, 2002. p. 75-80.

Carlson, R. E. A trophic state index for lakes. Limnol. Oceanogr., v. 22, p. 361-380, 1977.

Ceballos, B. S. O.; Lima, E. O.; Köning, A.; Martins, M. T. Spatial and temporal distribution of fecal coliforms, colifages, moulds and yeasts in freshwater at the semi-arid tropic Northeast Brazil (Paraíba State). Rev. Microbiol., São Paulo, v. 26, p. 90-100, 1995.

Coler, R. A.; Watanabe, T.; Xavier, B. F.; Paz, R. J. A preliminary report on the application of Macrobrachium amazonicum Heller, 1862 (Decapoda: Palaemonidae) as a biomarker. Hydrobiologia, v. 412, p. 119-121, 1999.

Coler, R. A.; Coler, R. R.; Felizardo, E. K. G.; Watanabe, T. Applying weight gain in Pomacea lineata (Spix, 1824) (Mollusca: Prosobranchia) as a measure of herbicide toxicity. Braz. J. Biol., v. 65, p. 617-623, 2005.

Eaton, A. D.; Clesceri, L. S.; Greenberg, A. E. (Ed.). Standard Methods for the Examination of Water \& Wastewater. New York: American Public Health Association Publications, 1995.

Gadelha, C. L. M.; Filgueira, H. J. A.; Campos, L. F.; Quinino, U. C. M. O uso de agrotóxicos nas áreas irrigadas da Bacia do Rio Gramame no Estado da Paraíba. Anais do $21^{\circ}$ Congresso Brasileiro de Engenharia Sanitária e Ambiental, Rio de Janeiro, 2001. 6 p.

Gesteira, T. C. V. Aspectos biológicos ligados à produtividade da pesca nos açudes públicos da área do "Polígono das Secas". Rio de Janeiro: Universidade Federal do Rio de Janeiro, 1978. (Masters Thesis).
Gonçalves, A. R.; Abdulkader, R.; Yu, L.; Malheiro, P.; Sabbaga, E.; Marcondes, M.; Burdmann, E. Tratamento da intoxicação por Paraquat: relato de dois casos e revisão da literatura. J. Bras. Nefrol., v. 14, p. 12-16, 1992.

Hellawell, J. M. Biological indicators of freshwater pollution and environmental management. London: Elsevier, 1989.

ICI. Paraquat e sua segurança no uso. São Paulo: Imperial Chemical Industry (ICI), 1990.

Luchini, L. C.; Lord, K. L.; Ruegg, E. F. Sorbtion and desorbtion of pesticides on Brazilian soils. Ciência e Cultura, v. 33, p. 97101, 1981

Medeiros, M. B.; Cruz, C. S. A. Principais produtos químicos responsáveis por acidentes de intoxicações em municípios da Paraíba. Rev. Bras. Agroecologia, v. 4, p. 3967-3971, 2009.

Medeiros, V. M.; Watanabe, T.; Coler, R. R.; Coler, R. A. Development of methods to assess the impact of herbicide use on the benthos of littoral impoundments in Northeast Brazil. Journal of Aquatic Ecosystem Stress and Recovery, v. 9, p. 67-71, 2001.

Melo, L. E. L.; Coler, R. A.; Watanabe, T.; Batalla, J. F. Developing the gastropod Pomacea lineata (Spix, 1827) as a toxicity test organism. Hydrobiologia, v. 429, p. 73-78, 2000 .

Melo, L. E. L.; Paz, R. J.; Barbosa, J. E. L.; Watanabe, T.; Batalla, J. F.; Coler, R. A. Chronic toxicity bioassay with ampularid snail Pomacea lineata (Spix 1824) (Mollusca: Prosobranchia). Brazilian Journal of Brazilian Sciences, v. 1, p. 28-34, 2014.

Muirhead-Thompson, R. C. Pesticide impact on stream fauna with special reference to macroinvertebrates. New York: Cambridge University Press, 1987.

Sanders, H. O.; Cope, O. B. Toxicity of several pesticides to two species of cladocerans. Trans. Am. Fish. Soc., v. 95, p. 165-169, 1966.

Schmitt, G. C.; Paniz, C.; Grotto, D.; Valentini, J.; Schott, K. L.; Pomblum, V. J.; Garcia, S. C. Aspectos gerais e diagnóstico clinicolaboratorial da intoxicação por Paraquat. J. Bras. Patol. Med. Lab., v. 42, p. 235-243, 2006.

Toledo, J. R., Jr.; Talarico, M.; Chinez, S. J.; Agudo, E. G. A aplicação de modelos simplificados para a avaliação de processos de eutrofização em lagos e reservatórios tropicais. Anais do XXII Congresso Brasileiro de Engenharia Sanitária, v. 1, p. 1-34, 1983. 
USEPA - United States Environmental Protection Agency. R.E.D. Facts: Paraquat Dichloride. Washington DC: USEPA Offices of Prevention, Pesticides And Toxic Substances, 1997.

Watanabe, T.; Coler, R. A.; Paz, R. J. The implementation of a regional biomonitoring program in northeast Brazil. Aquatic Ecosystem Health and Management, v. 2, p. 187-189, 1999.
Watanabe, T.; Oliveira, R. B. D.; Sassi, R.; Melo, G. N.; Gadelha, C. L.; Machado, V. M. N. Evidences of contamination caused by the sugar-cane monocultures and industry in water bodies of the State of Paraíba, Northeast Brazil. Acta Limnol. Brasil., v. 5, p. 85-101, 1994. 